\title{
The emergence of food waste as an issue in Swedish retail
}

\author{
Joacim Rosenlund \\ Linnaeus University, Kalmar, Sweden \\ Asa Nyblom and Hanna Matschke Ekholm \\ IVL Swedish Environmental Research Institute, Stockholm, Sweden, and \\ Louise Sörme \\ Statistics Sweden, Stockholm, Sweden \\ den, and
}

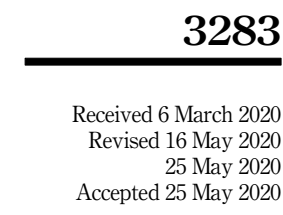

\begin{abstract}
Purpose - Food waste is acknowledged as a major environmental issue, but the retail sector has only begun to recognise this in recent years. The purpose of this paper is to answer when, how and why food waste became important for retail in Sweden.

Design/methodology/approach - A mixed-methods approach was used that included a literature review, quantitative data from retail, field studies, 11 interviews and a media study consisting of newspaper articles spanning 10 years. The combined methods provided qualitative rigor and saturation.

Findings - Results show that the increased interest in the issue stems from several factors working together. These factors include the availability of data, the formation of actor networks working together, increased societal environmental awareness, attitude change amongst consumers and retail, and the role of media as an actor and a method for making the issue visible. In addition, results show how the issue surfaced further, as more data became available. Findings suggest that food waste became an environmental issue, and later, the focus shifted to finding solutions for retail.

Originality/value - The results highlight the importance for policy to implement preventive measures and strengthen incentives for retail to work with reducing food waste. Such incentives should target cheap food, education, routines, legislation and business models throughout the food chain.
\end{abstract}

Keywords Supply chain, Retail, Food loss, Supermarket, Food policy, Food waste

Paper type Research paper

\section{Introduction}

Food waste is a global problem and Sustainable Development Goal 12 aims to "halve per capita global food waste at the retail and consumer levels and reduce food losses along production and supply chains, including post-harvest losses” (SDG 12.3). In a global perspective, the United Nations reports that about one-third of all food is lost (FAO, 2011), and this has a considerable economic and environmental impact. This is also highlighted in the latest IPCC report on land use and other studies identifying food waste as a global issue (Parfitt et al., 2010; West et al., 2014; FAO, 2011).

Food loss encompasses every stage of the food supply chain. Food waste occurs when an edible item is unconsumed at the end of the supply chain, including retail (Buzby et al., 2011; Priefer et al., 2016; Garrone et al., 2014), which is the focus of this study. Knowledge in retail about food waste is important due to the position of retail as a gatekeeper between production

(C) Joacim Rosenlund, Åsa Nyblom, Hanna Matschke Ekholm and Louise Sörme. Published in British Food Journal. Published by Emerald Publishing Limited. This article is published under the Creative Commons Attribution (CC BY 4.0) licence. Anyone may reproduce, distribute, translate and create derivative works of this article ( for both commercial and non-commercial purposes), subject to full attribution to the original publication and authors. The full terms of this licence may be seen at http:// creativecommons.org/licences/by/4.0/legalcode

The research was funded by the Swedish EPA grant number 802-0088-17, for the project analysing societal shift through food waste in supermarkets, report 6901. English Language Editor: Eva Tofvesson Redz.

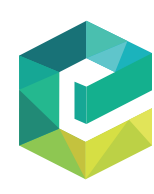

British Food Journa Vol. 122 No. 11, 2020 pp. $3283-3296$ Emerald Publishing Limited $0007-070 \mathrm{X}$
$03-2020-0181$ 
BFJ

122,11

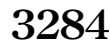

and consumption (Gruber et al., 2016; Teller et al., 2018). Furthermore, in retail, food waste has been acknowledged as an important issue that requires management (Buzby and Hyman, 2012; Mirabella et al., 2014; Scholz et al., 2015). While retail has taken action to reduce the environmental, economic and social impact of food waste (Swaffield et al., 2018) there is still work to be done.

The amounts and types of food waste generated in retail have been studied previously. In Swedish and Swiss examples, food loss in retail was low compared with other steps in the food chain (Beretta et al., 2013; Gustavsson and Stage, 2011; Andersson and Stålhandske, 2020). At the same time, it has also been argued that the retail stage has been overlooked as food waste is not always documented (Cicatiello et al., 2016; Cicatiello et al., 2017) although a study in Finland estimated food waste of 12-14 kg per capita and year in retail (Katajajuuri et al., 2014). The types of food that are most wasted include fruits, vegetables and bread (Eriksson et al., 2012; Mattsson et al., 2018; Katajajuuri et al., 2014).

The causes of food waste in retail vary; the desire to have shelves filled with products in the store (which generates overstocking), broken cold chains and errors in storing have been identified (Stenmarck et al., 2011; Mena et al., 2011). Studies have shown that food waste rates in retail also depend on the sales area, the number of purchases and the location. Other factors are organisational in character, and include packaging, turnover, shelf life, routines and demand (Lebersorger and Schneider,2014). The packaging also has an effect on shelf life, for example how expiration dates are displayed, and if the packaging is wholesale (Verghese et al., 2015; Eriksson et al.,2014), and as such, there is potential for packaging to reduce food waste(Wohner et al.,2019).

From a consumer perspective deviations to food shape, packaging or expiration dates are more accepted with appropriate discounts (De Hooge et al., 2017). Another study on consumer preference showed that consumers are less likely to buy suboptimal food if it leads to waste at home (Aschemann-Witzel et al., 2017a). Marketing strategies have also been proposed as a way to reduce food waste through changes in the distribution, communication, such as awareness campaigns, discounts and sales promotion (Calvo-Porral et al., 2017).

Donating food is already a common strategy in retail. For donations to work well, the logistics need to be sound and it has been shown that $40 \%$ of donated food remains uneaten (Alexander and Smaje, 2008). Depending on the value of the food, strategies other than donation can be viable, including selling for a lower price or disposal (Holweg et al., 2016), although disposing of the food to waste management is most common (Garrone et al., 2014).

Several other strategies to reduce food waste have been introduced, such as lowering quality standards and donation. Retailers' motivation to reduce food waste is based on awareness of the need for food donations, social responsibility and an altruistic feel-good factor. A German study showed the importance of consumer acceptance of lowered quality. Further donation was common, but was constrained by logistical challenges; the focus of such initiatives seemed to be more psychological and social, rather than economic (Hermsdorf et al., 2017). Changes in the supply chain with the aim to reduce food waste depend on factors such as time and place, collaboration, business opportunities and competences. These factors are also important for influencing consumer behaviour and donation of food (Aschemann-Witzel et al., 2017b).

In terms of looking at the people and management involved in retail food waste, one study found that those involved felt a moral burden to reduce food waste, but were restrained from taking action by their organisations. The room for micro level action and macro level restraint is a suggested area for future research (Gruber et al., 2016). Retail food waste was shown to be strongly correlated with human factors and waste reduction can be improved through staff training to optimise work routines (Teller et al., 2018). One study examined retail managers' attitudes to food waste and their strategies to reduce food waste. While most managers recognised the issue of food waste, it was downplayed in relation to corporate policies. Obstacles to mitigating food waste include consumer behaviour, policies, supplier and employee attitudes, and store size (Filimonau and Gherbin, 2017). 
The growing interest in food waste is most likely based on trends in society. However, the driving forces of these trends have not been exhaustively explored in previous research. One historical-sociological exploration of this question showed how interest in food waste increased during Second World War, only to be downplayed in the affluent decades that followed. Interest in the issue resurfaced in conjunction with the 2008 economic crisis and the subsequent global rise in food prices (Evans et al., 2012). In this paper, we aim to explain how changes in society generated a heightened interest in food waste on the retail side by answering the research question:

When, how, and why did food waste become important for retail in Sweden?

By answering this question we also aim to provide recommendations for retail and policy actors to manage food waste better throughout the chain. This paper is structured as follows: a methods section describing the mixed methods, results, discussion and conclusion. This study was carried out in a Swedish context, in which there are national goals to collect and treat food waste.

\section{Methods}

We worked in a transdisciplinary team, and used mixed methods to capture the societal shifts from different perspectives. These methods included literature analysis, media analysis, field studies and interviews in retail and with experts. These methods are described in this section. The literature review informed the field study, interviews and interview questions as well as the focus of the media study. The field study and media study were done simultaneously. To integrate the different methods we had continuous discussions in the project team and conducted an analysis workshop in the end of the project, were we made sense of the results.

\section{Literature review}

The literature review was conducted using Web of Science, using two main search patterns. The first was a search for "food waste" or "food loss" as a topic, and resulted in about 5000 articles. The 20 most relevant and cited articles were downloaded. The second was a search for "food waste" or "food loss" and "retail" or "supermarket", and resulted in about 130 articles. Irrelevant articles were eliminated based on the content of their abstracts, which left 77 articles that were subjected to the literature review. Reports relevant to the research question were also collected, by finding citations of these or through recommendations from experts. The review is presented as part of the introduction.

\section{Quantitative data}

The four stores were selected to represent varying size, number of employees (the sample could include stores with 5-499 employees), location and different retail chains. We preferred to choose stores that had separate collection of food waste, which would indicate an interest in the food waste issue.

\section{Field study and expert interviews}

As part of the field study, interviews were conducted in the four selected stores. One store manager and one employee were interviewed in each store, which is eight interviews in total. From each store we requested to interview long-term employees with experience of changes in the retail sector. Part of the interview was conducted during a walk around the store area. In addition to the store interviews, interviews were conducted with three experts. These experts were chosen, based on their experience and knowledge, from a list of experts in the areas of retail and waste. A list of the interviewees is available in Table 1, where they are identified as interviewees A-H and experts X-Z. The full quotes from the interviews are available in Table 2.

Interview questions were developed using a semi-structured format, in which areas of interest were identified based on the background literature and the aims of the study. Questions focussed
Emergence of food waste

3285 


\begin{tabular}{|c|c|c|c|c|}
\hline & Interviewee & Role/experience in retail & Place & Store \\
\hline & A & $\begin{array}{l}\text { Owner and manager } / 20 \mathrm{yrs} \text { of } \\
\text { experience }\end{array}$ & 1 small town & $\begin{array}{l}\text { Small store. } 5 \text { employees plus extra } \\
\text { personnel (total 9) }\end{array}$ \\
\hline & $\mathrm{B}$ & Employee/28 yrs of experience & 1 small town & $\begin{array}{l}\text { Small store. } 5 \text { employees plus extra } \\
\text { personnel (total } 9 \text { ) }\end{array}$ \\
\hline 3286 & $\mathrm{C}$ & $\begin{array}{l}\text { Owner and manager } / 14 \text { yrs of } \\
\text { experience }\end{array}$ & 2 small town & $\begin{array}{l}\text { Small store. } 9 \text { employees plus extra } \\
\text { personnel }\end{array}$ \\
\hline & $\mathrm{D}$ & Employee/25 yrs of experience & 2 small town & $\begin{array}{l}\text { Small store. } 9 \text { employees plus extra } \\
\text { personnel }\end{array}$ \\
\hline & $\mathrm{E}$ & Manager/30 yrs of experience & $\begin{array}{l}2 \text { central } \\
\text { location }\end{array}$ & $\begin{array}{l}\text { Large store. } 90 \text { employees plus extra } \\
\text { personnel (total 150) }\end{array}$ \\
\hline & $\mathrm{F}$ & Employee/11 yrs of experience & $\begin{array}{l}2 \text { central } \\
\text { location }\end{array}$ & $\begin{array}{l}\text { Large store. } 90 \text { employees plus extra } \\
\text { personnel (total 150) }\end{array}$ \\
\hline & G & $\begin{array}{l}\text { Owner and manager } / 20 \text { yrs of } \\
\text { experience }\end{array}$ & 2 small town & Medium store. 25 employees \\
\hline & $\mathrm{H}$ & Employee & 2 small town & Medium store. 25 employees \\
\hline & $\mathrm{X}$ (expert) & $\begin{array}{l}\text { Long experience from working } \\
\text { with food waste }\end{array}$ & - & - \\
\hline & Y (expert) & $\begin{array}{l}\text { Long experience from working } \\
\text { with food waste }\end{array}$ & - & - \\
\hline $\begin{array}{l}\text { Presentation of } \\
\text { interviewees }\end{array}$ & $Z$ (expert) & $\begin{array}{l}\text { Long experience from working } \\
\text { with food waste }\end{array}$ & - & - \\
\hline
\end{tabular}

on interviewees experience of and interest in food waste, what changes occurred in this interest and how they occurred. During the interviews, follow-up questions were asked that aimed to capture the stories of the interviewees. Interviews were recorded, transcribed and then analysed through NVivo, using thematic coding based on grounded theory (Strauss, 1987), going back and forth between detailed analysis and an overview (Hargreaves, 2008). The sample aimed to capture the perspectives of both managers and employees from a variety of locations as show in in Table 1. By qualitative criteria, field studies and interviews provided saturation, meaning that no further themes would be identified with more data (Saunders et al., 2018).

\section{Media study}

The media study was conducted in the Swedish database Mediearkivet (media archive), which consists of printed and digital media. The study examined newspapers and sectorspecific media between 2008 and 2017. Complementary searches were also made on Google. The search words consisted of the Swedish language equivalents of food waste and food loss. When this word search generated too many unrelated results, the words "retail" and "supermarket" were added.

Analysis and categorisation was carried out using NVivo. We analysed the material in terms of both quantity and quality. First, we examined how and when media reported about the issue, and then we posed three main questions: in what context was food waste presented, what is taken for granted or ignored and which actor "owns" the question, for example, politicians, authorities, consumers, companies or industry.

\section{Results}

An overview of food waste in retail is presented with the help of the media study, which identified three transitions in the Swedish context. These transitions are further analysed using results from interviews with experts and representatives of retail. 
Interviewee/quote

number

$\mathrm{X} 1$

$\mathrm{X} 2$

X3

$\mathrm{C} 1$

$\mathrm{Y} 1$

Y2

H1

Y3

G1

A1

B1

E1

G3

G4

Z3

F1

E2
Quote

I do not think this question exists in the media [the question you are trying to change], it does not exist. That is what I have learned in my 20 years [. . . ] if you want to change something you need some media buzz. Even when it is about politics. You may think that is sad. You think it should be all right to talk to each other about facts and other things. . . but it's when it enters the media something happens. That is my opinion Feedback has published a lot of reports and been a driver. Some amount of scandals as well to get the question up on the agenda

It was a question that this small island was being buried in a mountain of waste. So they had to do something. [-] It was probably just packaging that they looked at from the beginning. Then you saw that within the packaging there was a lot of food so they started to look at that. And then the process was initiated

The food is too cheap. The amount of income spent of food has drastically decreased in the latest decennia

Food is too cheap. It's cheaper to throw away than to take care of it

You think there is an expectation from the customers to have full shelves. You blame the consumers

A larger and broader assortment usually leads to higher amounts of waste, we talked a lot about that. But we will not decrease our assortment, it's the other way around. You need to work harder to sell the products in time, and be rigorous about that, if it is 2-3 days left it's better to sell the product so there is no waste

Maybe because of the decision on Agenda 2030 - do not know if [focus on the question in the public debate] has increased because the world has a goal to reduce its waste. If you want to acknowledge that in the media, that you know about the agenda Would I remove all my waste [...] then we would have increased the results by a million. It is a lot of money you could reinvest and do good things with, or support the employees

I am pretty cynical, but I think it goes back to the money. . . "Here we get some goodwill when we buy something that would have been thrown away" [by donating products to charity or other means]. That is a contributing factor

You did not lower the price on anything, you threw it away. Probably five or six big vessels that you threw it in. [...] So it depends a lot on who you work for - how environmentally aware they are. . . or how much they want to earn from it [what can be sold when the price is reduced]

It is a big cost so [.. . ] [regarding French rolls] maybe our view is that it's cheaper to do nothing at all, and to send it away so someone can pick it up. [Becoming animal feed instead]. But yes. . . eventually we might rethink and pay the cost as a store. But that's also a political question. That those who do it [...] should receive a sum When we follow up, often in different departments, you can have different goals in reducing waste. At the bread department we had to increase - we increased the waste. It sounds strange but. . . it was not enough for all customers. In the morning after it was empty. Then we could see quite quickly that it was not enough for everybody - we had to bake more and accept that we had to throw away more. You always had to find a balance of what is acceptable - economically or environmentally - or what you have the guts to throw away. At the same time you want it to be enough for everybody

Even if you are able to use the product today it is my perception that you want to buy the product with a long lifetime

An insight into the whole chain is lacking. That the different parts are affecting each other. The focus is largely on consumers and the end of the chain

I do not know what they do with the old products, maybe they sell it to someone else, I think so. Someone less picky. We are quite picky regarding the quality

They suck the yeast out of the bread [...] So that is good at least. They make breadcrumbs as well so they use everything [that is possible] and that is great
Emergence of food waste

3287

\section{-}


BFJ 122,11
Interviewee/quote

number Quote

C3

$\mathrm{C} 4$

Y6

D1
It is a lot of bureaucracy that stops [waste preventive measures] and that creates a lot of waste as well. There are a lot of rules to cope with, and sometimes incredible safety margins built into these which leads to a lot of food being thrown away

Here I actually break this rule, but I do not think it's OK [to throw it away] - it's great food! [.. . ] You get sad. You know - how many millions are starving? It is terrible Partly to bring the industry together to discuss the question, but also produce guidelines that makes it easier. Just because you think it's difficult to understand, legislation for example. Producing some guidelines that clarify. There might be legislation that makes it difficult and then you can see if it's possible to do something about it

8-10 yrs ago you did not document the waste and did not look at [any changes]. Everything was thrown away in bags. It changed with the automatic ordering systems. For these to work you need to register everything that is removed from the shelf - also that which is sorted out and thrown away. "If we throw away $1 \mathrm{~kg}$ of sweet pepper we need to register that in the computer, otherwise there will not be any new sweet peppers". So we worked like never before. Today you want to know in one way or the other what the waste is

Table 2.

\section{Media exposure}

Media was important for pushing the agenda of food waste, according to the expert and retail representative interviews. One of the experts (X1), highlighted the importance of media for a question to gain attention. The media study also showed this media attention quantitatively, as the media exposure of food waste and food loss increased, as shown in Figure 1.

There were 22 articles in 2008 and 720 articles in 2017 in local newspapers featuring the terms "food waste" and "food loss" in the heading. This can be compared with the literature review, which reported that 46 scientific articles contained "food waste" in the heading in 2008 and 333 articles in 2017. A search that covered retail and supermarkets showed three spikes, in 2010, 2013 and 2016, as shown in Figure 2, which warranted further qualitative analysis. These spikes will also serve as a thematic structure for the results presented below, which are intertwined with the interview results.

Figure 1.

Exposure in media of "matsvinn" (food waste) and "matavfall" (food loss) in newspapers. Total hits: 14 523. 10981 articles mention "matavfall", and 3542 articles mention "matsvinn"

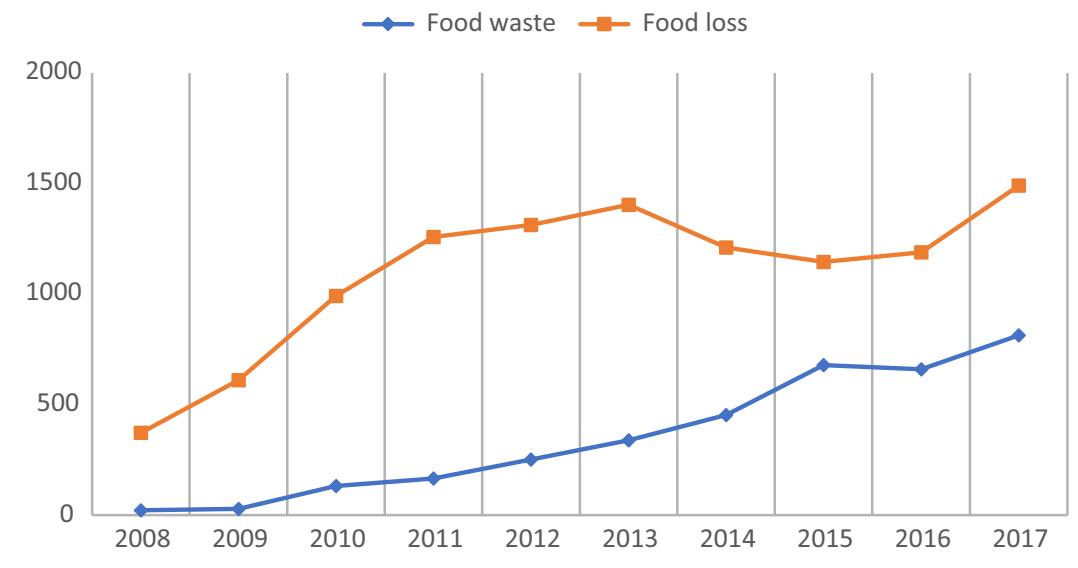


Presentation of interview data

Table 2 below includes the quotes used in the analysis in the coming sections. The quotes are identified by the interviewee code as presented in Table 1 and the number of the quote.

\section{Recognising food waste as a problem}

During the first spike, in 2010, media coverage focussed to a large extent on statistics. Media coverage of food waste began with data that described the scope of the issue in 2008-2010. Newspaper articles quoted various reports and statistics concerning how much food Swedes throw away. The newspapers also highlighted a retail manager who reduced food waste by $80 \%$ by repackaging food that would have been thrown away as ready lunches. In food sector-specific media, during this period the focus lay more on transforming food waste into a resource, and less about reducing food waste.

For a problem to be acknowledged, it must be visible; food waste came into the public eye after a number of reports, projects and organisations highlighted the extent of the issue. In Sweden, food waste was first measured in 2009 by the Stockholm Consumer Cooperative Society (Konsumentföreningen Stockholm, 2009), which also led to the formation of a network of actors working together to reduce food waste. This has also been described by the experts as the starting point (Z1):

Z1: It was then, when you got the numbers and were able to measure [that change occurred]. Even if it was not exact numbers, you started to see the amounts and started to talk.

The experts argued that compared to Sweden, some neighbouring countries had come much further in acknowledging food waste as a problem (X2 + 3). Examples from Norway showed that retail took the initiative, and data from Norway in 2015-2017 showed a 17\% drop in retail food waste (Elstad Stensgård et al., 2018). In the United Kingdom, the WRAP initiative (Waste and Resources Action Programme) was formed in 2000 and remains active. Data from this initiative showed a drop of 10\% in food waste from retail in 2007-2015 (WRAP, 2017, 2019). Norway and the United Kingdom acknowledged the question and addressed it, and had clear targets, policy instruments and financing. Sweden has had a fully operational waste management system for some time, which means that food waste has not been seen as an urgent priority; although, according to one expert, this has been not optimal from an environmental standpoint.

Managers and employees who were interviewed all agreed that low prices on food was the main problem that led to food waste. Throwing food away can be less costly than intervening to prevent food waste ( $\mathrm{C} 1$ and $\mathrm{Y} 1)$. The interviewees explained that consumers spend less and
Emergence of food waste

3289

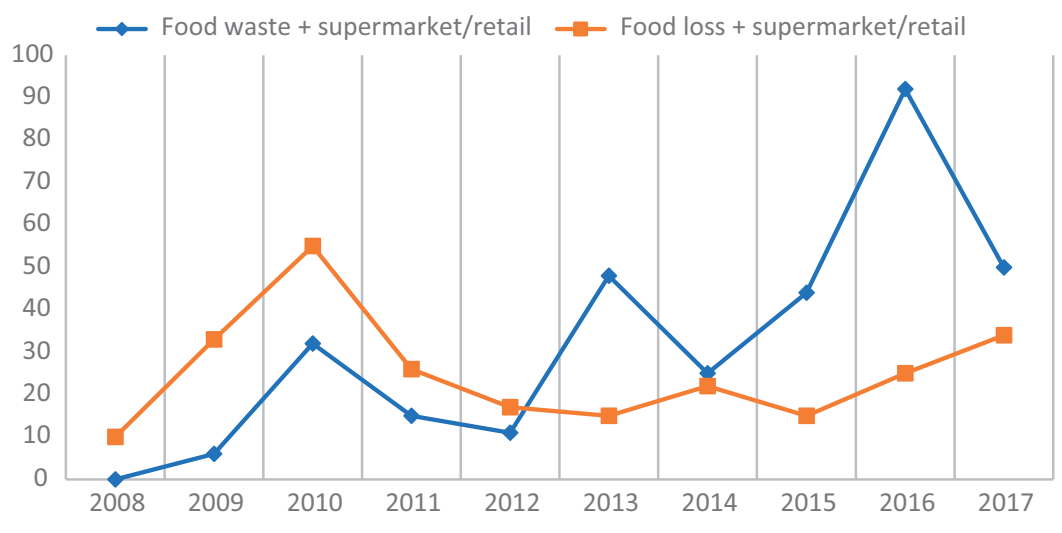

Figure 2 . "Matsvinn + butik/ handel" (food waste + supermarket/ retail) is mentioned in 323 articles.

"Matavfall + butik/ handel" (food

loss + supermarket/ retail) is mentioned in 252 newspaper articles 
$\mathrm{BFJ}$

122,11

less of their share of income on food, which leads to food being valued less. The attitude towards food amongst both customer and retail was also raised as an explanation (Y2). Retail has a need to keep shelves fully stocked, which, according to them, is what the customers expect. One interviewee stated that larger stores lead to more shelves that need to be filled, which leads to more food waste $(\mathrm{H} 1)$.

\section{Food waste as an environmental issue}

In 2013, the second spike is explained by a recognition of the question of food waste in general as a climate change issue and an environmental problem. Prior to that, the behaviour of consumers, as a group, was seen as the main driver of food waste; however, at this stage retail came into focus. During this year, there was also increased media coverage of good examples from retail, such as charity donations. The opportunity, but also the responsibility, for retail to act on the issue was thereby acknowledged.

A United Nations report in 2011 put the food waste across the chain as an issue on the international agenda (FAO, 2011). At the same time experts, retail managers and employees all saw the link between a growing environmental awareness and food waste. In Sustainable Development Goal 12.3, the UN 2030 Agenda also acknowledges food waste as an issue that needs to be addressed (Y3). According to one expert (X), an increased awareness of climate change helped the question of food waste to gain traction and, as such, one driver of change can benefit another. However, it took time for food waste to become an established environmental concern $(Z)$.

Retail managers and employees who were interviewed argued that the industry had always worked to reduce food waste. The reasons given for conducting such work were mainly the economic costs, rather than environmental concerns (G1) and the same interviewee continued:

G2: As long as I have worked in a store we have talked about waste and loss [. . .] As I remember it was more about economic aspects before. Now it's more talk about the environment and effects on the environment.

As retail acknowledged food waste as an environmental issue, this reason began to be used in combination with economic incentives to promote change. Retail also saw the promotional potential in addressing the issue (A1). The interviewees stated that there was less focus on food waste as an environmental issue $10 \mathrm{yrs}$ ago. The increased awareness amongst the consumers regarding food waste was also described by the interviewees. There has been an increasing acceptance amongst consumers for buying products with a short "best-before" date at a discount:

C2: Before it was only retired people that bought products with reduced pricing - short date wares. Now it's also younger and regular people that buy, because there is a larger awareness. They say "oh my, I'm gonna use it today so that's fine". That's nice.

The positive environmental effect made this alternative attractive to more customer segments than before. Interviewees from all stores confirmed that price reduction was an important measure to reduce food waste. One interviewee confirmed that price reduction was already used in the 1990s (B1). Another interviewee also confirmed that interest in food waste varies between stores depending on who owns or manages the store $(\mathrm{H})$.

However, implementing price reduction requires time and resources and according to one interviewed store manager, it is not always a profitable approach - especially with regard to low-price products (E1). It is also a matter of choosing to increase sales or reduce waste and the choice can vary in different parts of the store (G3). According to the interviewee, this calls for a balance between economic and environmental concerns. The retail sector might be concerned that their reputation will suffer if they start to lower their prices (Z\&A). There were 
also examples of customers who demanded fresh products, were fussy about the quality, and asked for milk with longer expiration dates (Interview G4). At the same time, the interviewees also noted that there was a change in attitude as consumers become more aware of the environmental impact:

Z2: It has changed, today you increasingly believe that consumers view it as positive when you try to reduce the waste in the stores. It give positive signals. You [the consumer] choose to buy the product for half the price because you feel that you do something for the environment - you do not need to be embarrassed for this

\section{Food chain, authorities and solutions}

During the 2016 spike and forward, the topic of food waste gained traction, framed as a problem throughout the food chain from producer to consumer. Here, the responsibility of authorities was also highlighted. In this period, the 2030 Agenda was cited and more good examples on proactive efforts to reduce food waste in retail were included in the media coverage. In 2017, many articles were published regarding higher taxes on waste in municipalities and a suggested (but not passed) law that would oblige municipalities to take care of the food waste.

The importance of focussing on the entire food chain in a search for solutions to the food waste problem was also highlighted in the interviews. Food waste in retail occurs, for example, when sales are difficult to predict, which can lead stores to overstock on products. Other food waste is less noticeable, such as when products are sent back to the supplier due to poor quality. Some stores send back all products, while others might send back only a few (F1). Furthermore, unsold bread is often returned to suppliers to make other products, such as yeast (E2) which is positive, as it turns waste into value. However, it could also be seen as negative, since it means there is a lack of incentive for the stores to reduce bread waste:

Y4: Why do we have this kind of system? Nobody really knows. It does not exist in other countries. If stores had responsibility for the bread they could sell even that cheaper.

Customers and retail have cosmetic demands on the products that make them difficult to sell. Numerous other factors throughout the food chain, such as transporting chilled food, have a very small margin for error. An overview of food waste from producer to consumer is necessary, although often challenging (Z3). The interviews also point to the fact that different actors in the food chain have different goals and powers, which can spur conflicts between the actors. Moreover, this dynamic often leads to guilt and responsibility for food waste being passed up or down the food chain to another actor (Y2).

The experts agreed that incremental measures were insufficient to adequately reduce food waste in retail. Furthermore, one of the experts asserted that the whole business model needs to be changed and all actors need to review their operations within the model:

Y5: The industry need to change their business model [---] Retail has done a lot of which is possible. You have not done anything revolutionary so that remains.

Thus far, retail has addressed the food waste issue mainly through information campaigns, in which customers are given "do's and don'ts" for avoiding food waste at home. However, these measures usually do not affect business practices in retail at all. The interviewees point to a conflict between efforts to reduce food waste and larger sales volumes (E). Discount campaigns, for example, may lead customers to buy more food than they need (X, Y, Z). Campaigns may also lead to unsold food, since they depend on consumers' interest in a particular product $(\mathrm{A}, \mathrm{E}, \mathrm{B})$, and when the stores buy more than they can sell this leads to food waste:

G5: The most important intervention according to me is buying the right amount of wares from the beginning [...] But, to increase sales we need to buy more to sell more, so it's not as
Emergence of food waste 
BFJ

122,11 easy as it sounds to just "buy the right amount", because we want to sell more and throw less away.

Legislation was often seen as an obstacle in reducing food waste in stores, according to the interviewed managers. Many regulations make it difficult for stores to do anything with products that are close to their expiration date $(\mathrm{C} 3, \mathrm{E})$. Regulations dictate that some foods can only be stored warm for a certain period of time, after which they may not be chilled or frozen, and must be wasted if left unsold. Another way to reduce food waste is to decrease temperatures for chilled products, but this, in turn, can be more costly $(\mathrm{X}, \mathrm{C})$. Managing the whole value chain means looking at all linked steps and opening up for collaboration, rather than competition, amongst the actors involved, which has been confirmed in previous research (REFRESH, 2019).

There are examples of store managers disregarding regulations to save food (C4); food that is safe to eat that became illegal to sell, which the managers thought it a shame to throw it away. In one interview, the interviewee suggested that expiration dates are arbitrary and should be decided by authorities rather than by the producers (A). This is another example of a problem with legislation and power relations throughout the food chain. The retail side perspective was that the legislation benefited wholesalers and that there were incentives to buy pre-packaged food rather than raw goods, which further inhibits food waste prevention at store level, according to an interviewed store manager (Ref). The experts also view legislation as a possible obstacle in retail's action against food waste (Y6, Z).

During this period, digital solutions began to appear in the media, with reports of applications, start-ups and initiatives to reduce food waste, and general advice to consumers. Digitalisation was also reported in the interviews as an approach that has increased the possibilities of saving food. Today, there are mobile applications, such as Karma, where would-be food waste is sold at reduced prices. In the stores, the overview of orders has improved as a result of new systems that can help monitor expiration dates (D1). The data provided by these systems make the food waste visible. In similar analogue solutions, stores set food waste reduction goals, thereby creating a positive culture of "no waste":

C5: It is important to be able to follow up "now we have thrown away this product-maybe we should not keep it". We need to analyse this all the time, what we throw away. So maybe you disappoint some customer but overall it's better for the Earth and our economy.

\section{Discussion and conclusion}

To answer when and how food waste became important for retail, we used the three identified media spikes and reflected on them based on the results of the interviews. The spikes helped us build a chronological account of when the changes happened and the thematic analysis aided us to construct a narrative account of the changes.

The first spike in 2010 was concerned with improved data and media coverage of food waste. In this period, a network of key actors formed and began to address food waste. These actors, in turn, were inspired by international examples. The incentive for retail was mainly economic in the early stages, although individual store managers were environmentally motivated for addressing the issue. Later, a heightened environmental awareness in society made it economically viable to tackle food waste. During the second spike, in 2013, food waste became an environmental issue for retail. Still, the results show that economic motives remain a higher priority in retail.

The third spike in 2016 was a shift towards a focus on solutions in retail, but thus far, these have been low-hanging fruit, motivated by economic or marketing values. During this spike, the importance of value chains and business models was established, and has also been described in previous research (Teller et al., 2018; Brancoli et al., 2019). Legislation was put forward by both managers and experts as a possible hindrance for practical efforts on waste 
prevention. Other managers described the possibilities that come with digitalisation. At the same time, managers relied on their level of autonomy when working within a retail chain. This level of autonomy has also been discussed in previous research as an important factor in reducing food waste, as it provides space for managers to address the issue (Gruber et al., 2016; Filimonau and Gherbin, 2017).

To answer why food waste became important for retail, we must look at the timing of the issue. Burgeoning interest in sustainability, in addition to increased visibility of food waste through data, reports and media also increased awareness of the food waste issue. Several factors worked together and piggybacked on each other to put food waste on the agenda in Sweden. The main factors recognised in our study are:

(1) Measurements made the issue of food waste as a problem visible;

(2) Formation of a network of actors worked to address the question;

(3) An increased focus on environmental and climate issues in society;

(4) Attitude change amongst consumers and in retail;

(5) The role of media and

(6) Digitalisation, which provided new tools.

Media was an important player in putting the food waste question on the agenda. The media spikes highlighted three transitions and media itself provided a momentum for the transitions by making the question visible and acknowledging that food waste was an environmental issue. An increased interest in environmental issues in the media also paved the way for food waste to be considered headline material. The media reported on exemplary solutions of retail stores and managers linked to the increasing environmental awareness of customers and managers. As the study was limited to Sweden, further research can look at the role of media in other countries and identify other factors that led to the emergence of food waste as an issue in retail.

Previous studies have shown that retailers take action based on environmental and social concerns, in addition to economic motivations (Swaffield et al., 2018; Tjarnemo and Sodahl, 2015). At the same time, evidence in other countries shows that economic reasons remain the most highly prioritised (Derqui et al., 2016). In our study, we saw how retail motivated a reduction in food waste with the environment in mind, although the motivation was intertwined with economic concerns. Retail maintains a balance between selling more and reducing waste. We recommend studies in other countries and cross-country comparisons regarding the motivation to reduce food waste in retail.

We recommend that policy strengthen incentives for retail to use preventive measures. Such preventive measures should target food that is cheaper to throw away than taking care of. Educating personnel and reviewing routines for managing food waste are other important measures. Reviewing legislation and business models throughout the food chain is also necessary (Teller et al., 2018). Power relations between actors need to be acknowledged as well and this is an area where authorities can step in. Policy actors can also provide incentives, or even be a driving force, for networks between actors in the food chain. The importance of autonomy for retail managers has also been shown in this and other studies (Gruber et al., 2016). Whether or not there is room for managers to implement any preventive measures is an important issue.

\section{References}

Alexander, C. and Smaje, C. (2008), "Surplus retail food redistribution: an analysis of a third sector model", Resources Conservation and Recycling, Vol. 52 No. 11, pp. 1290-1298.
Emergence of food waste 
BFJ 122,11

Andersson, T. and Stålhandske, S. (2020), Matavfall I Sverige: Uppkomst Och Behandling 2018, Naturvårdsverket, Stockholm.

Aschemann-Witzel, J., Jensen, J.H., Jensen, M.H. and Kulikovskaja, V. (2017a), "Consumer behaviour towards price-reduced suboptimal foods in the supermarket and the relation to food waste in households", Appetite, Vol. 116, pp. 246-258.

Aschemann-Witzel, J., De Hooge, I.E., Rohm, H., Normann, A., Bossle, M.B., Grønhøj, A. and Oostindjer, M. (2017b), "Key characteristics and success factors of supply chain initiatives tackling consumer-related food waste - a multiple case study", Journal of Cleaner Production, Vol. 155, pp. 33-45.

Beretta, C., Stoessel, F., Baier, U. and Hellweg, S. (2013), "Quantifying food losses and the potential for reduction in Switzerland”, Waste Management, Vol. 33 No. 3, pp. 764-773.

Brancoli, P., Lundin, M., Bolton, K. and Eriksson, M. (2019), "Bread loss rates at the supplier-retailer interface-Analysis of risk factors to support waste prevention measures", Resources, Conservation and Recycling, Vol. 147, pp. 128-136.

Buzby, J.C. and Hyman, J. (2012), "Total and per capita value of food loss in the United States", Food Policy, Vol. 37 No. 5, pp. 561-570.

Buzby, J.C., Hyman, J., Stewart, H. and Wells, H.F. (2011), “The value of retail-and consumer-level fruit and vegetable losses in the United States", Journal of Consumer Affairs, Vol. 45 No. 3, pp. 492-515.

Calvo-Porral, C., Faina Medin, A. and Losada-Lopez, C. (2017), "Can marketing help in tackling food waste?: proposals in developed countries", Journal of Food Products Marketing, Vol. 23 No. 1, pp. $42-60$.

Cicatiello, C., Franco, S., Pancino, B. and Blasi, E. (2016), "The value of food waste: an exploratory study on retailing", Journal of Retailing and Consumer Services, Vol. 30, pp. 96-104.

Cicatiello, C., Franco, S., Pancino, B., Blasi, E. and Falasconi, L. (2017), "The dark side of retail food waste: evidences from in-store data", Resources, Conservation and Recycling, Vol. 125, pp. 273-281.

De Hooge, I.E., Oostindjer, M., Aschemann-Witzel, J., Normann, A., Loose, S.M. and Almli, V.L. (2017), "This apple is too ugly for me! Consumer preferences for suboptimal food products in the supermarket and at home", Food Quality and Preference, Vol. 56, pp. 80-92.

Derqui, B., Fayos, T. and Fernandez, V. (2016), "Towards a more sustainable food supply chain: opening up invisible waste in food service", Sustainability, Vol. 8 No. 7, p. 693.

Elstad Stensgård, A., Prestrud, K., Hanssen, O.J. and Callewaert, P. (2018), Food Waste in Norway Report on Key Figures 2015-2017, Kråkerøy, Østfoldforskning.

Eriksson, M., Strid, I. and Hansson, P.A. (2012), "Food losses in six Swedish retail stores: wastage of fruit and vegetables in relation to quantities delivered", Resources Conservation and Recycling, Vol. 68, pp. 14-20.

Eriksson, M., Strid, I. and Hansson, P.A. (2014), "Waste of organic and conventional meat and dairy products-a case study from Swedish retail", Resources Conservation and Recycling, Vol. 83, pp. $44-52$.

Evans, D., Campbell, H. and Murcott, A. (2012), "A brief pre-history of food waste and the social sciences”, The Sociological Review, Vol. 60 No. 2, pp. 5-26.

FAO (2011), Global Food Losses and Food Waste - Extent, Causes and Prevention, Food and Agriculture Organization of the United Nations, Rome.

Filimonau, V. and Gherbin, A. (2017), "An exploratory study of food waste management practices in the UK grocery retail sector”, Journal of Cleaner Production, Vol. 167, pp. 1184-1194.

Garrone, P., Melacini, M. and Perego, A. (2014), “Opening the black box of food waste reduction”, Food Policy, Vol. 46, pp. 129-139. 
Gruber, V., Holweg, C. and Teller, C. (2016), "What a waste! Exploring the human reality of food waste from the store manager's perspective", Journal of Public Policy and Marketing, Vol. 35 No. 1, pp. 3-25.

Gustavsson, J. and Stage, J. (2011), "Retail waste of horticultural products in Sweden", Resources Conservation and Recycling, Vol. 55 No. 5, pp. 554-556.

Hargreaves, T. (2008), Making Pro-environmental Behaviour Work: An Ethnographic Case Study of Practice, Process and Power in the Workplace, University of East Anglia, Norwich.

Hermsdorf, D., Rombach, M. and Bitsch, V. (2017), "Food waste reduction practices in German food retail”, British Food Journal, Vol. 119 No. 12, pp. 2532-2546.

Holweg, C., Teller, C. and Kotzab, H. (2016), "Unsaleable grocery products, their residual value and instore logistics", International Journal of Physical Distribution and Logistics Management, Vol. 46 Nos 6-7, pp. 634-658.

Katajajuuri, J.M., Silvennoinen, K., Hartikainen, H., Heikkilä, L. and Reinikainen, A. (2014), "Food waste in the finnish food chain", Journal of Cleaner Production, Vol. 73, pp. 322-329.

Konsumentföreningen Stockholm (2009), Rapport frän en slaskhink, Konsumentföreningen Stockholm, Stockholm.

Lebersorger, S. and Schneider, F. (2014), "Food loss rates at the food retail, influencing factors and reasons as a basis for waste prevention measures", Waste Management, Vol. 34 No. 11, pp. 1911-1919.

Mattsson, L., Williams, H. and Berghel, J. (2018), "Waste of fresh fruit and vegetables at retailers in Sweden - measuring and calculation of mass, economic cost and climate impact", Resources Conservation and Recycling, Vol. 130, pp. 118-126.

Mena, C., Adenso-Diaz, B. and Yurt, O. (2011), "The causes of food waste in the supplier - retailer interface: evidences from the UK and Spain”, Resources, Conservation and Recycling, Vol. 55 No. 6, pp. 648-658.

Mirabella, N., Castellani, V. and Sala, S. (2014), "Current options for the valorization of food manufacturing waste: a review", Journal of Cleaner Production, Vol. 65, pp. 28-41.

Parfitt, J., Barthel, M. and Macnaughton, S. (2010), "Food waste within food supply chains: quantification and potential for change to 2050", Philosophical Transactions of the Royal Society B: Biological Sciences, Vol. 365 No. 1554, pp. 3065-3081.

Priefer, C., Jörissen, J. and Bräutigam, K.R. (2016), "Food waste prevention in Europe - a cause-driven approach to identify the most relevant leverage points for action", Resources, Conservation and Recycling, Vol. 109, pp. 155-165.

REFRESH (2019), Policies against Consumer Food Waste, available at: https://eu-refresh.org/policiesagainst-consumer-food-waste.

Saunders, B., Sim, J., Kingstone, T., Baker, S., Waterfield, J., Bartlam, B., Burroughs, H. and Jinks, C. (2018), "Saturation in qualitative research: exploring its conceptualization and operationalization”, Quality and Quantity, Vol. 52 No. 4, pp. 1893-1907.

Scholz, K., Eriksson, M. and Strid, I. (2015), "Carbon footprint of supermarket food waste”, Resources, Conservation and Recycling, Vol. 94, pp. 56-65.

Stenmarck, A., Jörgen Hanssen, O., Silvennoinen, K. and Katajajuuri, J.M. (2011), Initiatives on Prevention of Food Waste in the Retail and Wholesale Trades, Nordic Council of Ministers, Stockholm.

Strauss, A.L. (1987), Qualitative Analysis for Social Scientists, Cambridge university press, Cambridge.

Swaffield, J., Evans, D. and Welch, D. (2018), "Profit, reputation and 'doing the right thing': convention theory and the problem of food waste in the UK retail sector", Geoforum, Vol. 89, pp. 43-51.

Teller, C., Holweg, C., Reiner, G. and Kotzab, H. (2018), "Retail store operations and food waste", Journal of Cleaner Production, Vol. 185, pp. 981-997.
Emergence of food waste

3295 
$\mathrm{BFJ}$ 122,11

Tjarnemo, H. and Sodahl, L. (2015), "Swedish food retailers promoting climate smarter food choicestrapped between visions and reality?", Journal of Retailing and Consumer Services, Vol. 24, pp. 130-139.

Verghese, K., Lewis, H., Lockrey, S. and Williams, H. (2015), "Packaging's role in minimizing food loss and waste across the supply chain”, Packaging Technology and Science, Vol. 28 No. 7, pp. 603-620.

West, P.C., Gerber, J.S., Engstrom, P.M., Mueller, N.D., Brauman, K.A., Carlson, K.M., Cassidy, E.S., Johnston, M., MacDonald, G.K., Ray, D.K. and Siebert, S. (2014), "Leverage points for improving global food security and the environment”, Science, Vol. 345 No. 6194, pp. 325-328.

Wohner, B., Pauer, E., Heinrich, V. and Tacker, M. (2019), "Packaging-Related food losses and waste: an overview of drivers and issues", Sustainability, Vol. 11 No. 1, p. 264.

WRAP (2017), "Surplus food redistribution in the UK 2015 to 2017", available at: http://www.wrap. org.uk/sites/files/wrap/Food $\% 20$ Surplus $\% 20$ Redistribution $\% 20$ Estimate $\% 202017 \% 20$ - $\% 20$ Information \% 20sheet.pdf (accessed 25 May 2020).

WRAP (2019), "Food surplus and waste in the UK - Key Facts", available at: https://wrap.org.uk/sites/ files/wrap/Food_\%20surplus_and_waste_in_the_UK_key_facts_Jan_2020.pdf (accessed 25 May 2020).

\section{Corresponding author}

Joacim Rosenlund can be contacted at: joacim.rosenlund@lnu.se

For instructions on how to order reprints of this article, please visit our website:

www.emeraldgrouppublishing.com/licensing/reprints.htm

Or contact us for further details: permissions@emeraldinsight.com 